\title{
Tid for tango?
}

Etter rusreformen i 2004 fikk rusavhengige pasientrettigheter og lovfestet rett til tverrfaglig behandling. Vi i Tyrilistiftelsen ble pålagt å ansette leger. Men det var ikke så lett. Fagfeltet rus- og avhengighetsmedisin har lav status, pasientgruppen er lite attraktiv for legene og en ideell stiftelse klarer ikke å matche lønnen leger kan få andre steder. Rusavhengige Bjørn Axel Bentsen sto nylig frem og sa at han vurderer å «søke» etter ny fastlege via en annonse. Det inspirerte oss til selv å lage følgende kontaktannonse på vegne av fagfeltet.

«Jeg er en impulsiv, idealistisk og spennende sjel som leter etter den rette; en kunnskapsrik, medmenneskelig og åpensinnet lege. En jeg kan støtte meg på i gode og ikke fullt så gode dager. En som vil bli gammel sammen med meg.

Det koster å spørre. Det er ikke så lenge siden jeg ble sett og anerkjent for den jeg er. Derfor har jeg kanskje ikke den samme tryggheten og erfaringen som andre fagfelt du har hatt et forhold til. Men endelig våger jeg å ta initiativ. Tiden er inne for å åpne opp og innrømme at jeg trenger deg og at du kan berike livet mitt.

Litt om meg selv: Jeg er en romantiker og en idealist, og jeg tror at det umulige er mulig. Jeg er utstyrt med sterk vilje og mye nestekjærlighet. Jeg tror på likeverd og betydningen av at mennesker får like muligheter til å utvikle seg. Men jeg mener også at mennesker skal behandles ulikt når forutsetningene er ulike, slik at de med dårligere utgangspunkt får mer støtte.

I møte med andre er jeg omgjengelig. Jeg etterstreber å få andre til å kjenne seg verdsatt og respektert. Jeg lar andre få plass til å uttrykke sine egne tanker, ideer og vurderinger, selv om det kan vekke ubehag. Jeg mener at hvis ulike syn får komme frem, bidrar det til å belyse en sak fra flere sider og legger grunnlaget for å finne nye og bedre løsninger.

Jeg bruker hele følelsesregisteret mitt og gir av meg selv. Jeg er lys til sinns det ene øyeblikket, mørk i det neste. Impulsiv, uforutsigbar og spennende. Jeg har måttet lære meg å improvisere. Lært meg å le av utfordringene. Men jeg har aldri vært spesielt redd for nærkontakt. Akkurat der er vi like.

Jeg er optimistisk og har sterk tro på egne og andres krefter. Du kan si jeg er naiv. Men jeg bærer på så mye erfaring og så mange historier. Jeg har kommet ut av det med tro på at det gode skal seire.

Du har sikkert vært en del rundt. Levd livet. Solt deg i psykiatri og somatikk, i fiffige diagnoser og dyre maskiner. Jeg klandrer deg ikke. Og jeg vet at det finnes mange som vil ha deg, selvfølgelig er det det.

Venner har forsøkt å koble oss. Rusreformen skapte rammer rundt oss slik at vi skulle møtes. Hittil har jeg spilt kostbar. Tenkt at jeg ikke trenger deg. Kanskje for- søkte jeg å beskytte meg selv? Jeg kommer fra trange kår. Jeg er ikke like belest som deg. Jeg har ikke vært i gamet like lenge som deg. Du - som er sterk og trygg på deg selv og har mange i ryggen. Du som fremstår som erfaren og verdensvant. Jeg fokuserte på ulikhetene og trodde ikke at vi skulle klare å finne balansen. Jeg trodde du skulle komme glidende inn med dine vanskelige ord, beskyttede titler og fremforhandlede rettigheter og ta over livet mitt. Overkjøre alt jeg hadde tilegnet meg av kunnskap og erfaring gjennom årene. Men nå skjønner jeg at jeg trenger deg og at hverdagen er mer fattig uten deg.

Jeg kan ikke love deg gull og grønne skoger. Jeg er ikke den peneste, jeg er ikke rik, jeg kan ikke dele ut fine titler og tilby enorme karrieremuligheter. Jeg står ikke i fremste rekke og glitrer, jeg er veggpryden som lett blir oversett eller glemt.

Og jeg er ikke uten motstand. Jeg kommer til å insistere på å bli hørt. Og du må lytte. Du må aldri la meg være i tvil om at vi er på samme lag. Og jeg håper at jeg kan gjøre deg stolt. For du er en som tar folk på alvor. Du er en som fortsatt husker det du lærte det første halvåret på studiet: at det er mennesker det handler om, når alt kommer til alt.

Det må to til for å danse tango. Og nå er det min tur til å bli bedt opp til dans. Er du klar?»

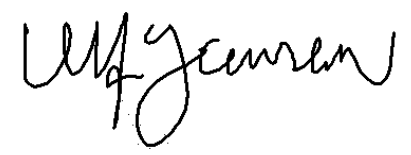

